December 2006

\title{
Anti-Haitianism, Historical Memory, and the Potential for Genocidal Violence in the Dominican Republic
}

Edward Paulino

Follow this and additional works at: https://digitalcommons.usf.edu/gsp

\section{Recommended Citation}

Paulino, Edward (2006) "Anti-Haitianism, Historical Memory, and the Potential for Genocidal Violence in the Dominican Republic," Genocide Studies and Prevention: An International Journal: Vol. 1: Iss. 3: Article 5 .

Available at: https://digitalcommons.usf.edu/gsp/vol1/iss3/5

This Articles is brought to you for free and open access by the Open Access Journals at Digital Commons @ University of South Florida. It has been accepted for inclusion in Genocide Studies and Prevention: An International Journal by an authorized editor of Digital Commons @ University of South Florida. For more information, please contact digitalcommons@usf.edu. 


\title{
Anti-Haitianism, Historical Memory, and the Potential for Genocidal Violence in the Dominican Republic
}

\author{
Edward Paulino \\ History Department, CUNYIJohn Jay College of Criminal Justice
}

\begin{abstract}
Following the 2005 murder of a Dominican woman near the border between the Dominican Republic and Haiti, Haitian communities were deported en masse and their homes violently ransacked by Dominican civilians seeking revenge. These violent expulsions were not only human-rights violations but part of a historic pattern of anti-Haitianism in the Dominican Republic that originated in the nineteenth century. This article calls attention to the possibility of genocidal violence in the Dominican Republic by examining the violent 2005 attacks on the Haitian community there. It suggests that an anti-Haitian legacy that includes the 1937 Haitian Massacre and the contemporary and systematic denial of Dominican citizenship to Dominicans of Haitian descent are important but understudied indicators that raise the potential for an escalation of mass violence against the largest ethnic and racial minority in the Dominican Republic.
\end{abstract}

Between May and September 2005, nearly 3,000 Haitians living in the Dominican Republic were deported to Haiti. ${ }^{1}$ These massive deportations came on the heels of the murder of a Dominican woman near the Dominican-Haitian border. The murder sparked a series of pogrom-like attacks against Haitian communities throughout the Dominican Republic. Men, women, and children were forcibly removed from their homes by the Dominican military, many of them stripped of their identity papers, and herded onto trucks and school buses. In several towns, Dominican civilians looted the abandoned wooden shacks that Haitians called home, taking anything of value. Unwanted items were removed from the houses and burned. ${ }^{2}$ The deportees were taken to various towns along the border by the Dominican military. Upon arrival, they waited for hours under the unforgiving Caribbean sun, without food or water. Eventually, the military ordered the Haitian passengers to exit the buses and walk across the border into Haiti-a nation many had never visited.

Many of the "Haitian" deportees were not immigrants. They were born and raised in the Dominican Republic: bicultural and bilingual persons, Dominican-Haitians, whose parents were long-time residents on Dominican soil. Although Haitians have been living in the Dominican Republic for more than a century, and constitute the nation's largest ethnic minority, they are excluded from the right to Dominican citizenship. $^{3}$

At birth, Dominicans of Haitian descent are systematically denied birth certificates-the prerequisite for obtaining la cedula, the national ID card. Without this card, which contains biographical information such as blood type, skin complexion, height, and weight, a person is unable to obtain important government documents such as passports or drivers' licenses. For the most part, Dominicans of Haitian descent also

Edward Paulino, "Anti-Haitianism, Historical Memory, and the Potential for Genocidal Violence in the Dominican Republic." Genocide Studies and Prevention 1, 3 (December 2006): 265-288. (C) 2006 Genocide Studies and Prevention. 
cannot vote or otherwise participate in the political life of the country. In short, they are unable to integrate into the Dominican body politic.

At the same time, ethnic Haitians in the Dominican Republic represent an indispensable source of labor to be exploited. In the agricultural, home-construction, and private-security sectors, Haitian labor is ubiquitous and an essential part of the Dominican economy. The Haitian presence is evident in any major Dominican city or small town, and this demographic reality is not new. Their presence is a result of a long history of intra-island movement and collaboration, specifically along the 300-mile border that separates the two republics. For example, twice a week, Dominican border towns host market days, during which Haitians can enter freely to trade with Dominican merchants. This is a remarkable example of mutual cooperation and a vibrant local economic enterprise that dates back to the eighteenth century.

Notwithstanding this collaborative history, there is also a genocidal history that precedes the most recent attacks on the Haitian community and points to an ominous future. The year 1937 saw the most violent attack on Haitians in Dominican history. The Dominican military conducted a genocidal campaign to remove all Haitians from the Dominican Republic; thousands of Haitians were killed or fled into neighboring Haiti, becoming political refugees. Ordered by the dictator Rafael Trujillo (1930-1961), this event marked the modernization of anti-Haitianism: the state sponsored institutional and ideological campaign to turn Haitians into the official enemy of the Dominican state. Although anti-Haitianism has its historical roots in the early $1800 \mathrm{~s}$, Trujillo and his intellectuals would, in unprecedented fashion, crystallize a historic but diffuse anti-Haitian sentiment into official government discourse. Starting after the massacre in 1937 and lasting through 1946, this nationalistic state doctrine sought to erase the historic and collaborative history between the two peoples while promoting xenophobic government policies along the border. ${ }^{4}$ Unfortunately, this anti-Haitian sentiment outlived the dictatorship, remaining solidly entrenched in Dominican society for subsequent generations.

For the last sixty years, the Dominican government has been unwilling to accept the legacy of the 1937 massacre and its moral responsibility for this crime against humanity. Moreover, along with the rhetoric of opportunistic politicians who manipulate anti-Haitian rhetoric, this violent past partly explains why a systematic government policy to scapegoat and deport Haitians has emerged and intensified in recent times. Dominican authorities contend that, like other sovereign nations (they often cite the US policy of deporting immigrants), the Dominican Republic has the right to expel persons whom authorities believe to have entered the country illegally. Yet this latest round of deportations is disturbing, both because of their spontaneous grassroots intensity and because they were sanctioned by government policies that reject the inclusion of Haitian ethnicity as part of a larger pluralistic Dominican society.

The focus of this article is to expose the recent and ongoing hostility against Haitians in the Dominican Republic and to argue that this violence merits special attention because of its proto-genocidal nature. The recent anti-Haitian violence in the Dominican Republic should not be seen as an isolated event, as a case in which the majority population simply deports a racial and ethnic minority. Anti-Haitian prejudice and discrimination, combined with anti-black racism, permeates all levels of Dominican society. Haitians are viewed as the black "other," culturally incapable of assimilating. The situation is more ominous today because the Dominican Republic has many features generally considered key prerequisites for the organization and 
perpetration of mass murder: the existence of a stigmatized racial/ethnic minority group within the dominant society; the political and economic disenfranchisement of that minority group; and the historical precedent of state-sponsored mass murder. Taking these and other factors into account, I argue that unless preventive measures are taken to integrate this minority group, the current state policy of violent deportations or ethnic cleansing will mean that future and more intensified genocidal violence against Haitians cannot be ruled out in the Dominican Republic. ${ }^{5}$

\section{A Murder Awakens Historic Animosities}

In early May 2005, several Haitians in the Dominican border town of Hatillo Palma invaded the home of Domingo Luna and his wife, Maritza Núñez, both in their early thirties. The assailants knew their victims; they were neighbors and on friendly terms. Unfortunately, familiarity and goodwill ended in a violent death that would reverberate across the nation. In the confrontation, Maritza was killed; her husband barely survived teeth-crushing machete blows to his mouth. The assailants were eventually captured. But what happened next is all too familiar in the realm of ethnic violence.

Stirred by the murder, Dominican residents of Hatillo Palma retaliated by expelling all of their town's Haitian residents. The word spread quickly, and Haitian residents throughout the community were told they had until 6:00 p.m. to leave town. Fearing for their lives, Haitians abandoned their homes. As they fled, their Dominican neighbors descended upon the abandoned wooden shacks previously rented to Haitian workers and began looting their possessions. Unwanted items were removed from the houses and burned. According to local residents, the murder represented the breaking point in a series of violent Haitian attacks on Dominicans over the previous year. ${ }^{6}$ Apparently, Maritza's murder was the straw that broke the camel's back.

By the time I arrived in the town on 29 May, almost three weeks after the murder and civilian rampage, there were no Haitians left. In a town where Haitians had constituted a significant percentage of the population and economy, the scene was surreal. One long-time Dominican resident told me, "I will pay you money, if you see a Haitian walking down the street. We don't want Haitians here. We don't want them!" The action was not without its costs, however. Echoing many who told me that the expulsion of the Haitian community represented an economic blow to the town, one resident, an employee of a betting parlor, told me the following story: "Before the expulsion, I used to sell $\$ 1,000$ RD [US\$35] daily in lotto tickets. Now, I sell about $\$ 600$ RD [US\$21]. But I am glad they are gone. You can only take so much.”

Fueled by relentless nationwide media reports describing the murder of a defenseless Dominican woman by Haitians, the violent attacks spread to other towns.

In response to the attacks on Hatillo Palma and the surrounding areas, the army and immigration officials began rounding up Haitians throughout the Dominican border region, under the pretense of "protecting" them from vigilante mobs. ${ }^{7}$ I visited several semi-urban and rural Haitian communities from which long-time residents had been deported. Every story was heart wrenching. Take, for example, the case of one-year-old Mari, a Dominican-Haitian who, along with most of her community near the northwestern border, was removed to Haiti during the initial deportations of May 2005. With the help of organizations such as Solidaridad Fronteriza, many deportees, including Mari, were able to return to the Dominican Republic. ${ }^{8}$ Others, Mari's mother among them, were not so fortunate. At the time, Solidaridad Fronteriza 
was petitioning the Dominican government to allow persons like Mari's mother to return to the Dominican Republic. But the scars that these deportations had inflicted were already evident in the faces of the children. According to a Dominican neighbor who was caring for Mari, the little girl had fallen physically ill and was mentally distraught at the loss of her mother.

Many of Mari's adult neighbors, who worked and raised families in the Dominican Republic, had also been deported. Even those who had some form of legal documentation had their identity papers taken from them or destroyed. An example is the case of Pedro. During the deportation raids, Pedro, a Haitian father of eleven and a farmer, awoke to the sight of Dominican soldiers, brandishing rifles, who had forced themselves into his small wooden shack. The soldiers handcuffed him and deported his entire family. He says that in the early-morning raids of 13 May, the army stole his entire savings- $\$ 6,000 \mathrm{RD}$, the equivalent of about US $\$ 200$ at the time..$^{9}$ Like many deportees who endured several grueling days in Haiti, Pedro's family returned to the Dominican Republic with the help of religious and human-rights organizations. But Pedro did not have his identity cards, given by the immigration department, because the soldiers had ripped them up during the initial raids. Despite having resided for many years in Dominican territory, he was deported. He ultimately did make his way back into the Dominican Republic to rejoin his family, but not without first injuring his leg in the process. Others who owned businesses, such as small stores, were also deported. Such arbitrary deportations of Haitians and their descendants have been occurring with growing frequency since the early 1990s. Human Rights Watch (HRW) has summed up the situation as follows:

Suspected Haitians are targeted for deportation based on the color of their skin, and are given little opportunity to prove their legal status or their claim to citizenship. As a rule, people facing deportation from the Dominican Republic have no chance to contact their families, to collect their belongings, or to prepare for departure in any way. They are frequently dropped at the Haitian border within a matter of hours after their initial detention, sometimes with nothing more than the clothes on their back. ${ }^{10}$

The Maritza Núñez murder-the killing of a Dominican woman by Haitiansprovoked such intense anger that it inspired violent and unprecedented civilian backlash. In the southern border region, in the town of Enriquillo, near the major southwestern city of Barahona, Father Jesus Alvarez, a Spanish priest who works for the Spanish Institute of Foreign Missions in defense of Dominican and Haitian rights, reported that following the murder of Maritza, a mob of over 100 people mobilized in the town to search for Haitians. The mob, disproportionately composed of adolescents, carried bats and sticks and wore hoods to hide their identity. Father Alvarez himself was threatened for denouncing the nationwide deportations of Haitians. ${ }^{11}$ The attacks prompted the editorial staff of one Dominican daily to write,

It is the obligation of all to condemn vehemently the violence that is carried out in the Northwest (border region) against Haitian immigrants, documented or undocumented, because the Ku Klux Klan hood does not suit Dominicans. ${ }^{12}$

But why should Dominicans retaliate so violently against their Haitian neighbors? Where does this Dominican fear and contempt for Haitians originate? As the next section shows, the recent mass expulsions of Haitians represent the latest chapter in the historical legacy of anti-Haitianism in the Dominican Republic. Indeed, part of the explanation lies in how the Dominican Republic emerged as an independent nation in the nineteenth century. 


\section{A History of Antagonism}

Historically, Dominicans have viewed Haiti, and Haitians migrating to their country, as a profound threat. The 1791 slave revolt in Saint Domingue (present-day Haiti) terrified slave-owning societies throughout the Americas. ${ }^{13}$ No society felt the repercussions of this tumultuous political upheaval more than the Spanish colony of Santo Domingo, on the eastern end of the island of Hispaniola.

By 1801, Toussaint L'Ouverture had marched into Santo Domingo in the east and captured the city, intent on the unification of the island. About 2,000 Santo Domingo residents fled the city, fearing the worst. ${ }^{14}$ In 1802 , Napoleon sent an expedition to restore slavery on Hispaniola. Toussaint and his army fled Santo Domingo but would subsequently defeat the French troops, eventually declaring the birth of the Republic of Haiti in 1804. A year after Haiti's declaration of national independence, Haitian forces under J.J. Dessalines marched eastward across the island to expel the French forces that had remained in Santo Domingo after Toussaint's flight in 1802. The Haitian logic was clear: to oppose a potential future European invasion and the restoration of slavery through the unprotected eastern part of the island. Haitian forces were unable to capture the city, but in their retreat westward, the army left a bloody trail of carnage. Haitian soldiers wreaked havoc in the Dominican countryside, destroying several cities and massacring many of their inhabitants. ${ }^{15}$ This event, underscored by future Dominican historians, would mark the origins of future Dominican antipathy toward Haiti. ${ }^{16}$ But the nineteenth-century event that would forever engrain itself in the Dominican memory, and influenced its view of Haiti, was the unification of the island by Haitian forces from 1822 to 1844.

What Haitians called "unification" was designed to protect their country from re-enslavement. But the Spanish colonists (particularly the white and mulatto slave owners) on the eastern end of the island saw it as an invasion. This "invasion" sparked a Dominican Creole-led movement for national independence, which was attained in 1844 and is to this day celebrated every 27 February in the Dominican Republic. $^{17}$

From its inception, then, the Dominican nation (particularly as constructed by its elites) has literally been based on the rejection of Haiti. The Dominican Republic is the only country in the Americas to have gained its independence from another former colony: Haiti. Between 1844 and 1856, the Dominican Republic repelled three unsuccessful Haitian military invasions; it then willingly returned to the colonial fold, annexing itself to Spain in 1861. It became permanently independent in 1865, after a successful national liberation movement (1863-1865) which threw off the shackles of European colonialism once and for all. ${ }^{18}$ Nevertheless, it was the expulsion of the Haitians in 1844 that became the seed of Dominican nationhood. It was this event that, through manipulation by the country's elite, would endure in the Dominican historical memory: Haitians as invaders.

In the modern (post-1900) era, Dominican anti-Haitianism can be traced most importantly to the 1937 massacre of Haitians-arguably one of the most egregious genocidal massacres in the Western hemisphere in the twentieth century. Although estimates of civilians killed range from as low as 4,000 to as high as 35,000, we will never know with certainty the exact number of casualties. ${ }^{19}$

The dictator Rafael Trujillo and his government bear full responsibility for the thousands of ethnic Haitians murdered in 1937. One of the most damning archival 
documents of this era comes from US Ambassador Henry Norweb, who wrote to Franklin Delano Roosevelt about the atrocities:

apparently with the approval of President Trujillo, a systematic campaign of extermination was directed against all Haitian residents in an area from some thirty kilometers south of Dajabón north to Monte Cristi. The drive was conducted with ruthless efficiency by the National Police and Army. ${ }^{20}$

The killings were not limited to the border but occurred throughout the country, except on US-owned sugar mills and plantations, where Haitian workers were spared. Neither Trujillo nor subsequent administrations ever faced charges for this crime against humanity, let alone accepted responsibility.

On 31 January 1938, a few months after the massacre, the Dominican and Haitian governments formally and peacefully settled their differences. But Trujillo refused to acknowledge responsibility for his government's complicity in the killings. According to the League of Nations treaty,

The Dominican government which for its part does not admit that the Dominican State is in any way responsible, but will on this point abide by the findings of the judicial inquiry, which is not yet concluded, agrees to terminate by a settlement all dispute. $^{21}$

The same agreement also "liquidates and terminates definitively by means of a settlement all claims whatsoever on the part of the Haitian Government or persons of Haitian nationality against the Dominican Government or against persons of Dominican nationality."22 This settlement legally absolved Trujillo of any responsibility for his complicity in mass murder and staved off potential future lawsuits.

Sixty years after the massacre, there are neither commemoration ceremonies nor monuments dedicated to the victims and legacy of this event. ${ }^{23}$ The massacre is mostly seen as a manifestation of a dictatorial government. Dominicans believe that they should not be held accountable for this brutal act. Moreover, during the recent wave of deportations, many Dominicans, in numerous conversations, eerily and nostalgically recalled the 1937 massacre as a valid response to the overwhelming and unwanted Haitian presence in their country. ${ }^{24}$ The failure to apologize and publicly assume responsibility for the massacre has left an anti-Haitian legacy whereby the political exclusion and physical removal of Haitians from the Dominican nation is generally justified and condoned. The legacy of the 1937 massacre and deportations, combined with a pervasive stigmatization of the Haitian minority and recurring economic crises in Dominican society, supply many of the ingredients that could lead to a future outbreak of genocidal violence.

\section{Applying a Genocide Early Warning System to the Dominican Republic}

There is no clear indicator to forecast mass murder. However, Israel Charny has proposed a Genocide Early Warning System (GEWS) that offers to "continuously monitor information on violations of human rights and ... to learn how to predict and alert people to the increasing dangers of mass murders in different societies before they occur." 25 Applied to the Dominican Republic today, GEWS social indicators suggest that a real potential for future anti-Haitian genocidal violence exists. These social indicators are

(1) Orientation toward force for self-defense and solution of conflicts: turning threats into an exercise of self-defense 
(2) Overt violence and destructiveness

(3) Dehumanization of a potential victim target group

(4) Perception of victim groups as dangerous

(5) Legitimization of victimization by leadership individuals and institutions

The situation of Haitians in the Dominican Republic today conforms with many of these indicators. Let us examine each in turn.

\section{(1) Orientation toward Force for Self-Defense and Resolution of Conflicts:} Turning Threats into an Exercise of Self-Defense

Current anti-Haitian policies continue to seek the reduction, if not the erasure, of Haitians from the Dominican landscape. Haitian migrants and their Dominican-born children are consistently stigmatized for their poverty, ethnicity, and dark skin, in a society that perversely values whiteness and in which racist acts occur with impunity. There is also a virulent and influential anti-Haitian discourse promoted by certain political elites. A strong sentiment exists among many in Dominican society that a new Haitian invasion is underway. "Self-defense" means reinforcing the Dominican-Haitian border to limit the flow of Haitian immigrants.

Like the current immigration debate in the United States, in which the US-Mexico border is seen as ground zero, the Dominican government sees its border as the nation's most vulnerable site to be defended. Ever since the era of the Trujillo dictatorship, the security of the Dominican border has been the responsibility of the army. Today, partly as a reaction to the events of 11 September 2001 and the "War on Terror," the Dominican government has created a Special Forces Commando Unit: an elite group drawn from the country's navy, air force, army, and national police. This multifaceted unit will provide additional support to the army in patrolling the border. ${ }^{26}$ Yet, despite the militarization of the region, the border, more than 300 miles long, remains highly porous. One of the main responsibilities for the Dominican Army along the border is to apprehend and repatriate undocumented persons, and particularly Haitians. In one month in 2004 alone, the Dominican Army, in conjunction with immigration authorities, apprehended and repatriated nearly 2,000 Haitians along the border. ${ }^{27}$ As we have seen, the threat of being overwhelmed by Haiti and her people has been a common trope in Dominican security discourse since 1844 .

\section{(2) Overt Violence and Destructiveness}

Colloquial references to a "silent invasion" from what the late and anti-Haitian president Joaquín Balaguer referred to as la isla al revés ${ }^{28}$ ("the backward island") are commonly used to describe both the consistent migratory flow from Haiti and the long-standing and demographically significant Haitian community within the Dominican Republic. Many Dominicans believe that the estimated one million Haitians already living in the country represent a threat to the Dominican nation and her people. There is no shortage of hyperbole, whether in the Dominican press or in public discourse, warning readers of the dangers that Haitian immigrants pose to the nation. Many Dominicans cloak their anti-Haitianism in either nationalistic rhetoric or talk of Haiti's economic and political malaise, arguing, as one Dominican congressman said to me, that Haiti "lacks state institutions, [that] its society is disintegrating and therefore [it] is not a viable country."29 
Many Dominicans fear that the political, economic, and environmental anarchy that has gripped Haiti will spill over across the border in the form of more Haitian migration. They often point as well to the catastrophic levels of deforestation that can be seen more markedly on the Haitian side of the border, where there is almost complete erosion, while the Dominican side is comparatively green and lush. ${ }^{30}$ They point to this as just one more example of Haitians' inability to govern and administer their society.

As Ervin Staub has written, "Given a preexisting devaluation and history of mistreatment, recent increases [in discrimination, harm and violence] represent an immediate danger signal." 31 In the Dominican case, as the sensationalist portrayal of Maritza's murder by the Dominican media intensified, the deportations provoked a violent backlash against Haitians. Three days after Maritza's murder, two Haitian corpses were found in Santiago, the nation's second-largest city. According to the coroner, these men died of internal hemorrhage and shock caused by gunshot wounds. ${ }^{32}$ The attacks on Haitians were not limited to the northern border, where Maritza's murder occurred. Throughout the border region and beyond, the attacks on Haitians were alarming for their quantity and cruelty. In late May, the decapitated body of a Haitian man was found in the southern border town of Pedernales. His wife, who was five months pregnant at the time, survived the attack but sustained multiple injuries. $^{33}$

Although these attacks failed to register with most American mainstream media, international human-rights organizations denounced the incidents, even labeling them explicitly as "ethnic cleansing." 34

The murderous attacks and roundups that followed the Maritza murder were not limited to poor Haitians living and working in rural areas; Haitian university students in the Dominican Republic were also targeted for deportation and abuse. At a large student gathering at one of the major universities, the Universidad Tecnológico del Cibao (UTESA), Haitian students voiced to immigration authorities their fear of being targeted by the arbitrary deportations and xenophobia gripping the nation at the time. According to Jean Ferdino, president of the Haitian Student Committee, "We have come legally to this country to study. We are not responsible for the criminal acts committed by other Haitians. We need spiritual and emotional tranquility to study." 35

Between May and August 2005, more sporadic attacks against Haitians took place. In mid-August, the most shocking of such assaults occurred in the capital, Santo Domingo: four Haitian immigrants were attacked and set on fire. Three of the four succumbed to their injuries. ${ }^{36}$ Tensions ran high between the countries as a result of these attacks. Haiti even recalled its top diplomat (at the time, the chargé d'affaires) to protest the brutal killings, which, on the heels of the deportations, seemed to many observers to signal open season on Haitians in the Dominican Republic. ${ }^{37}$

By this time, the prominent non-profit organization known as El Movimiento de Mujeres Dominico-Haitiana (Movement of Dominican-Haitian Women, or MUDHA) was already investigating many of the violent incidents in Haitian and DominicanHaitian communities. In September 2005 alone, nine Haitians and Dominicans of Haitian descent were murdered, apparently as part of the wave of violent antiHaitianism. ${ }^{38}$ Two attacks reminiscent of that in Hatillo Palma took place in August and December 2005. In one, the lifeless body of a seven-year-old Haitian girl was found brutally raped and dismembered in the province of Valverde, near the border. Dominican residents attacked a Haitian community, setting fire to their homes and injuring several with machetes and clubs. In another case a "rampage followed the 
discovery of the body of thirteen-year-old Dominican Diómedes (or Dicórides) de Jesús Caba, reportedly stabbed to death by an undocumented Haitian whose name is given as 'Federico Pierre." "39

In December, a similar retaliatory pogrom to that of Hatillo Palma occurred in the central Cibao region, near the town of Moca. In response to the killing by Haitians of a well-known and beloved Dominican moneychanger in the small town of Villa Trina, a mob of local Dominicans descended upon a nearby Haitian hamlet. According to sources, thirty-five houses were burned in this once-vibrant community, which served as a labor pool for the surrounding coffee plantations. ${ }^{40}$

No clearer example of overt violence and sheer destructiveness as a warning signal for the escalation of ethnic conflict can be found than what occurred following the murder of Dominican Maritza Núñez. Between May and December 2005, aided by a media campaign that repeatedly ran articles on the porous border with Haiti, Haitians and their communities were attacked violently throughout the country by Dominicans eager to exact revenge or settle local scores. The eight-month assault by civilians and government authorities left dozens of Haitian men, women, and children dead, countless displaced and their homes destroyed.

\section{(3) Dehumanization of Potential Victim Target Group}

The modern and graphic dehumanization of Haitians in the Dominican Republic begins with the 1937 Haitian Massacre. For its speed and intensity, this was the largest killing of black people en masse in the Americas in the twentieth century, and, as I have shown, it established a dangerous legacy of anti-Haitianism that has persisted to the present. ${ }^{41}$ In a seminal study on anti-Haitian prejudice conducted in the second-largest Dominican city, Santiago, researchers found that the antiHaitianism that had existed since the inception of the Dominican nation intensified after the genocidal massacre of 1937. This quantitative and qualitative study concluded that anti-Haitianism consists of three types of prejudice: ethnic, class, and racial. ${ }^{42}$ At the core of anti-Haitian prejudice is anti-black racism. Ever since the successful Haitian Revolution in 1804, residents, and particularly elites, of the eastern end of the island have viewed Haitians as the perennial and dangerous "black other." This

racism involves prejudice and discrimination. It may be personal or institutional, felt or unrecognized, but it is normally based on a stereotype that people of a particular genetic background all behave in some unappealing way; they all do, they have no choice, it is in the genes. ${ }^{43}$

The dehumanization of Haitians and their descendants takes many forms. One of the most famous cases of blatant anti-Haitianism involved a former presidential candidate, now deceased, named José Francisco Peña Gomez. A former mayor of Santo Domingo, a nationalistic student who protested against the 1965 US invasion, and a high-ranking member of the International Socialist Party, Peña Gomez was poised to win the 1994 presidential elections against the octogenarian neo-Trujillista incumbent, Joaquín Balaguer. He ultimately lost to Leonel Fernandez, the current president, whose PLD party made the crucial and historic pact with Balaguer (the "Pact of Democracy") to acquire the critical votes to win the presidency. Aside from political intrigue and voter fraud, the dark-skinned Peña Gomez was the object of a vicious racial campaign. His political opponents labeled him as either Haitian or of Haitian descent. They warned Dominicans that history would repeat itself if a "Haitian" 
became president, and that this would usher in another Haitian invasion of the eastern end of the island. ${ }^{44}$

Perhaps the most effective example of Haitian dehumanization in the Dominican Republic, aside from the government's policy of deportation, is the guiding principle and ubiquitous practice of political disenfranchisement. Long-term Haitian residents and their children are systematically denied the right to Dominican citizenship; many are undocumented in the only country they have ever known. Of course, there is also the additional problem of under-documentation for non-Haitian Dominicans. According to a spokesperson for the Centro Dominicano de Asesoría e Investigaciones Legales (Dominican Center for Consulting and Legal Investigations, or CEDAIL), "there are entire communities in the southern part of the country where there are as many as 50,000 people with no birth certificates"; "up to the present, there has been no attempt to create a mass registration of the undocumented persons." ${ }^{4}$ For Haitians, however, the situation is qualitatively different. For example, unlike non-Haitian Dominicans and those of lighter hue, Haitian women giving birth on Dominican soil must register their children at the Haitian consulate. ${ }^{46}$ Although pregnant Haitian women are admitted to Dominican hospitals to give birth, the emotional and psychological toll is very high. For example, in 2003, I accompanied my wife's uncle to the maternity ward at the Robert Reid Cabral Hospital in Santo Domingo. He was the senior doctor on call. I inquired whether there were any Haitian women who had given birth, and some nurses pointed to a woman in the ward. We approached her, and my wife's uncle asked the woman if she was Haitian. The tears rolling down her cheeks, as she nursed her infant child, confirmed that she was frightened of us and feared being deported.

In 2000, an immigration bill (Article 166) was submitted to the Dominican Congress that would prohibit hospitals or clinics in the Dominican Republic from admitting foreign pregnant women. ${ }^{47}$ The legislation was clearly meant to deny Haitian women the human right to give birth. As one commentator facetiously wrote about this illogical legislation, "You would have to place guards at the entrances of the emergency rooms with the mission of intercepting every woman with an advanced state of pregnancy that exhibits a Haitian 'appearance.' "48 The bill did not become law, but Haitian immigration is still seen as exacerbating already declining conditions in Dominican hospitals. In the maternity ward at Santiago's Hospital Regional José María Cabral y Baez, $45 \%$ of all women giving birth in 2004 were Haitian. ${ }^{49}$ According to one doctor, "When all these patients arrive together, our budget is very limited, and then it appears that we would have grave difficulties." 50 And then there is the contentious issue of citizenship.

According to article 11 of the Dominican constitution, Dominican citizens are all those born in Dominican Republic, except children of diplomats or people "in transit." It is this latter category that has been used by numerous Dominican governments to discriminate against Haitians. According to a 2002 HRW report,

People who lived in the country for years, even decades, are thus squeezed into a category designed for brief and casual visitors. Some authorities even claim that all Haitian migrant workers, whether in the country legally or illegally, are "in transit" for the purposes of citizenship rules... Crucially, because all Haitians are considered "in transit," their Dominican-born children are not entitled to Dominican citizenship. $^{52}$

In the 1990s, sensing a gross misinterpretation of the constitution, several NGOs filed a suit against the Dominican government for systematically excluding the 
Dominican-Haitian community from citizenship. In October 2005, the Inter-American Court of Human Rights in Costa Rica ruled unanimously that the Dominican government had discriminated against two young Dominican girls of Haitian descent by denying them birth certificates. ${ }^{53}$ The court ordered the Dominican government to issue birth certificates to these girls, along with a total indemnity payment of $\$ 22,000$ and an official apology. ${ }^{54}$

For many human-rights activists, the Inter-American Court ruling was groundbreaking, because it offered a first step toward recognizing the rights of Dominican-Haitians. Unfortunately, the ruling did not deter the Dominican government from cementing the political exclusion of this minority population. Just two months later, the Dominican Supreme Court ruled unanimously that "children of undocumented [Haitian] immigrants born and raised in the Dominican Republic are not entitled to citizenship." 55 This ruling from the Dominican Republic's highest court reveals a society in which international standards of inclusion and democracy, at least with respect to the Haitian minority, are irrelevant.

For Haitians in the workforce, this lack of legal documentation leads to exploitation. Haitians are exploited for their cheap labor, and this condition is exacerbated by their inability to denounce the abuses they experience. The most famous case is that of the sugar-cane industry, where conditions have been described as modern-day slavery. ${ }^{56}$ Sugar-plantation authorities threaten Haitian cane cutters with deportations and often use this mechanism to avoid paying their workers. Among the many Haitians who migrate to the Dominican Republic, children are exposed to abuse by unscrupulous scouts (resembling the "coyotes" along the US-Mexican border) who are paid to escort undocumented persons across the border. The trafficking of Haitian children is a thriving market in both Haiti and the Dominican Republic. Apparently, it is quite easy to buy children's services. According to one observer, "You just ask around town. People know who the scouts are. You just tell them what kind of child you are looking for and they can bring across whatever it is that you want." 57

As the "coyote" analogy suggests, Haitian migrants are not unlike Mexicans trying to enter the United States in search of employment. Members of both groups will risk their lives to achieve socioeconomic progress. But in the skewed and rancorous antiHaitian discourse that prevails in the Dominican Republic, immigrant lives take a back seat to nationalist posturing. The terms of the debate are only undermined when tragedy strikes. Reminiscent of the tragedy in which nineteen Latin Americans were asphyxiated in a trailer truck near Victoria, Texas, in early 2006, twenty-four Haitians were found suffocated in the Dominican Republic. ${ }^{58}$ There is one important difference between Mexican and Haitian immigrants, however: the former benefit from a large and organized Mexican/Latino community (many of them citizens) in the United States, which lobbies effectively against anti-immigrant policies, whereas the Haitian community in the Dominican Republic enjoys no comparative organizational advantage and is not able to exercise the political or economic power to influence Dominican lawmakers.

The victimization of Haitians and their children is legally, economically, and socially pervasive. From the state exclusion denying citizenship, to deportations, to exploitative working conditions and a social prejudice that permeates all levels of Dominican society, bigotry and discrimination are both de facto and de jure. 


\section{(4) Perception of Victim Group as Dangerous; (5) Legitimization of} Victimization by Leadership Individuals and Institutions

According to the Council on Foreign Relations, ethnic violence in general results from two factors: "Tensions structured or perceived along ethnic lines, often intensified by misinformation that spreads quickly in times of crisis; and political leadership that promotes it or fails to halt it." 59 There is no doubt that in times of political and economic crises, ethnic minorities are targeted as scapegoats. In the Dominican Republic, Haitians and their descendants are targeted and stereotypically portrayed as foreign invaders taking away jobs from Dominicans. Dominican leaders often stoke the embers of anti-Haitian antagonism in the press. Consider the statements of current Dominican President Leonel Fernandez. While on a stumping trip to Puerto Rico, trying to mobilize support for his 2004 presidential bid, Fernandez-himself once an immigrant in New York-openly supported general amnesty for the thousands of undocumented Dominicans residing in the Commonwealth of Puerto Rico. Yet he neglected to mention the hundreds of thousands of long-term Haitian residents or the Dominicans of Haitian descent born and raised in the Dominican Republic, who are denied citizenship. He even warned Dominicans in Puerto Rico that, if illegal Haitian immigration was not stopped, there would be "an ethnic war something akin to what occurred in Kosovo." $" 60$

For Fernandez the politician, then, all immigrant groups are not equal. Dominican immigrants who live abroad (e.g., in Puerto Rico), and who have access to US dollars, should be treated fairly-especially those who are of "good character." But it seems that for Fernandez, particularly during a political campaign, there are no Haitians of good character. He echoes the fear of many Dominicans that their country will be overwhelmed by Haitian immigrants. ${ }^{61}$

Unfortunately, Fernandez is not alone in this scare-mongering. Dozens of newspapers and magazine articles echo his sentiment that Haitians represent a threat to Dominican national security. In an op-ed piece entitled "Kosovo and Haiti," a Dominican company executive writes angrily of the Dominican dependency on Haitian labor and warns of a future when Haitians will take over the Dominican Republic. He uses the Yugoslav model to illustrate his point:

As we can see, a simple Serbian province (Kosovo) at a determined time, and because of a government as well as the general Serbian population's carelessness, discovered suddenly that the Albanians were the majority who demanded their independence. $^{62}$

In his weekly newspaper column, a well-known former Trujillo aide shares his anecdotes as a young man meeting the dictator and hearing him talk about the "Haitian question." He writes that Trujillo "showed us his hands as testimonial evidence to tell us, "they are stained with blood, to save your generation from the Haitianization of the nation. " 63 Such xenophobic rhetoric is more alarming when one considers that the 1937 massacre is very much part of the immigration discourse deployed today in response to Haitian immigration.

A similar article echoes the warning of another Kosovo, speculating that Haitian immigration might become a sort of fifth column in the Dominican Republic. The fear among many Dominican nationalists (as they define themselves) who propose an end to this immigration is that, if unchecked, these Haitian migrants will become 
permanent residents in the country and eventually, as a bloc, secede from the Dominican Republic through the ballot box:

Let's suppose that Haitians for example become the majority in Barahona [a southern Dominican province near the border] and tomorrow allege, in their condition of ethnic majority and [with] some legal claims, to demand its annexation to Haiti or to declare some type of provincial autonomy. Would we Dominicans be in a position to give up part of our territory or declare the autonomy of some province for these reasons? The moment requires Dominicans to pay serious attention. The situation in Kosovo is not as distant as it seems. ${ }^{64}$

Even more worrisome is that these articles and public comments do not issue from extremist or marginal voices within Dominican society; the authors are very much part of the mainstream, often high-ranking officials. For example, Joaquín Ricardo, a former secretary of foreign relations, writes that "the problem is there and becomes thornier and more complex because everyday we have more Haitians in Dominican territory." ${ }^{25}$ Not only are politicians warning of being overwhelmed by Haitian immigration, but individuals in the military have also voiced their concerns. The former head of the Dominican Armed Forces, General José Miguel Soto Jimenez, has argued in an article entitled "Grave Amenaza" ("Grave Threat") that, rather than illegal drugs or weapons, it is Haitian immigration that represents the most serious threat to the security of the Dominican Republic. ${ }^{66}$

Many high-ranking officials and ordinary Dominicans support the removal of Haitians through deportations. The former president of the Universidad Autonoma de Santo Domingo (UASD), Roberto Santana, ticked off a litany of individuals who support a deportation policy. ${ }^{67}$ Ironically, even international observers, such as the former head of the United Nations in the Dominican Republic, Dr. Pablo Oberti, have supported (indirectly) the repatriations of Haitians. Oberti urged the Dominican authorities to conduct the repatriations with "sensitivity and comprehension."68 Bernardo Vega, a former Dominican ambassador to the United States and author of several important Dominican-Haitian-themed books, also voiced his opinion during the deportations of the 1990s:

I consider that the presence of that [Haitian] labor is not advantageous for the Dominican Republic; with the help of organizations like the United Nations, a peaceful and civilized repatriation of Haitians who are illegally in my country should be promoted. ${ }^{69}$

For Vega, the presence of Haitian labor in the Dominican Republic "promotes Dominican anti-Haitianism." He offers three seemingly simple recommendations for "an efficient deportation mechanism." First, Vega recommends a policy of voluntary return to Haiti, with the assistance of community and religious groups. Second, and subsequently, Dominican industries would be inspected to discover those employing undocumented Haitians, and employers would be fined if found in violation of immigration laws. Third, a policy of forced deportation would be instituted. Of all these stages, Vega finds the last the most difficult. Aside from forcing people (often violently) from a country that they may have resided in for years and called home, he recognizes that the difficulty in enforcing this policy is "defining who really is [a] Haitian who resides illegally in the country." ${ }^{70}$ Unfortunately, the deportation of Dominicans of Haitian decent has already occurred and is continuing; but these egregious human-rights violations have also drawn the attention and ire of the 
Dominican and Haitian diasporas in the United States. The violent deportations in the Dominican Republic after May 2005 prompted a member of the New York City Council to draw up a resolution condemning the attacks on Haitians:

At home here in the United States and in my native country of the Dominican Republic, I am always proud to lend my voice to the causes of fair immigration policy, due process and the protection of worker rights. It is critical that we have solidarity to support such basic human rights, and this resolution is a vehicle for the New York City Council to do just that. ${ }^{71}$

Dominicans living abroad and their children clearly see through the hypocrisy of Dominican immigration policy toward Haitians. The struggle for identity and place in the United States has politically galvanized the Dominican and Haitian communities, which have seen their families separated by deportations.

\section{Conclusion}

This article has shown that contemporary anti-Haitian violence in the Dominican Republic has its roots in the nineteenth-century Wars of Independence and the 1937 Haitian Massacre. What can be done to ensure that current policies of ethnic cleansing, such as deportations and denial of citizenship to long-term Haitians and their children in the Dominican Republic, do not intensify in the future? I believe that the fundamental responsibility lies with the political, economic, and military decision makers in the Dominican Republic itself. A paradigm shift is in order.

The Dominican Republic, a country where globalization is embraced by government and private industry alike, has failed to globalize the way in which it preserves its past, particularly in relation to its historic relationship with Haiti and the 1937 massacre. Unlike other countries such as Peru, Germany, Guatemala, Cambodia, and Rwanda, the Dominican Republic has failed to apologize as a nation for its participation in one of the hemisphere's most egregious twentieth-century examples of ethnic cleansing.

Dominican immigration policy must cease to depict Haitians as the historic enemy. Popular anti-Haitian discourse manipulated by xenophobic elites must be challenged by the state, and more institutional bilateral projects on the model of Fwontyè Nou - Nuestra Frontera should be established. ${ }^{72}$ Such programs could reduce and potentially eliminate the enmity to which every generation of Dominicans has been exposed, from the nineteenth century onward. This will be difficult, of course, since the roots of anti-Haitianism lie at the very heart of Dominican nationalism and patriotism: the creation of the Dominican nation involved a rejection of Haiti. A new type of Dominican nationalism and identity must emerge in order for all Dominicans to view Haiti as their long-term partners. A first step would be to initiate a cathartic national discussion about the role of Dominicans in the $1937 \mathrm{killings,}$ which, despite being factually incorporated in the academic historiography, are remembered as solely the responsibility of the dictator Trujillo.

Debates similar to those in other countries about historic participation in the destruction of ethnic minority groups must take place in the Dominican Republic. The most recognizable example of such negotiations over historical memory is German society's attempt to comprehend why their ancestors participated in the killing of Jews and other minorities. Dominicans, too, must ask, How could our countrymen and -women have participated, in 1937 and in more recent times, in the killing, burning, maiming, and deportations of their Haitian and Dominican-Haitian neighbors? ${ }^{73}$ The 1937 massacre should also be remembered by Americans, 
who especially should be made aware of this event because President Roosevelt, as is painfully evident in the diplomatic correspondence, was aware of the killings-and chose not to interfere. ${ }^{74}$

In the last ten years, there has been a global movement to acknowledge the historical wrongs of national pasts. From the Truth and Reconciliation Commissions in Guatemala and South Africa to breaking the silence of forgotten massacres, such as El Mozote in El Salvador and Trieste in Italy, the need to remember and come to terms with one's national past has gained momentum. ${ }^{75}$ Benedict Anderson has described how important it is for citizens to feel and express shame for their nation's past mistakes and crimes. Using the case of America's role during the Vietnam War, Anderson writes that Americans “felt ashamed that 'their' country's history was being stained by cruelties, lies, and betrayals. So they went to work in protest, not merely as advocates of universal human rights, but as Americans who loved the common American project." He adds that "this kind of political shame is very good and always needed." 76 Dominicans need to explore this collective shame, not only in relation to Trujillo's genocidal policy against Haitians in 1937 but also in relation to the human-rights violations that continue today. At a minimum, this type of discourse will go a long way toward changing the dynamic of the current policy concerning Haitians.

The Dominican Republic, like many countries around the world, has its share of xenophobic politicians and ultra-nationalists, who see Haitian immigration as a threat to their cherished way of life. Such nativistic responses are echoed, for example, in Europe, where politicians such as Austria's Jorg Haider or France's Jean-Marie Le Pen have made a name for themselves advocating punitive anti-immigrant and racist policies. On African immigration to his town, the mayor of Treviso, near Venice, has stated that Italians "have a 2,000-year-old civilization," while African immigrants to his town "know only the civilization of the savanna and the jungle"-comments thoroughly reminiscent of anti-Haitian discourse in the Dominican Republic. ${ }^{77}$

Many Dominicans I interviewed shared heart-wrenching anecdotes about growing up black and of Haitian descent in the Dominican Republic. Many spoke of seeing friends and family deported and experiencing real prejudice on an everyday basis. ${ }^{78}$ My interviewees spanned the spectrum of Dominican-Haitian life in the Dominican Republic: lawyers, NGO workers, students, and day laborers. Without exception, they had all experienced directly or indirectly racist behavior by Dominicans, from racial slurs to deportations. Perhaps the statement that best captures the DominicanHaitian desire to become part of the Dominican nation is that of Sonia Pierre, the executive director of MUDHA. Her struggle for equal rights is emblematic of a community that seeks democratic integration into the Dominican nation but is institutionally excluded:

We are here and for as much as we are not recognized as a group, they [the government] sees us [as] dangerous. The fact that we are a minority, that enrages people, but, well, we understand that we, children of Haitian immigrants, are a minority. We were born here. We are trying to educate ourselves here; we want to participate, we want to contribute...but we want to be recognized; there is a segregation here, if you will, toward this [Haitian] population, and so we are not seen as part of the Dominican identity, we are not seen as part of that [cultural] syncretism; it's much easier to accept any Dominican of any origin than a Dominican of Haitian origin. ${ }^{79}$

For many in the Dominican Republic, Haiti's weak or absent institutions and the country's political turmoil represent a "grave threat." 80 But portraying Haiti as 
a threat to Dominican society is the wrong way to conceptualize the future of both nations. Rather than seeing Haiti as a security challenge or as a burden, Dominican policy makers should, at every level, invest in a re-conceptualization of their relationship with their neighbor that will address the following questions: How can we create and implement a long-term and sustainable vision for both nations? What are the policies that need to be implemented today in order to sustain population increases tomorrow?

According to the US State Department, there are at least 8,833,634 people in the Dominican Republic, and at least 7,656,166 in Haiti, for a total of 16,489,800 people on an island whose surface area is the equivalent of the American state of Maryland plus two New Hampshires. What will the population of Hispaniola be in 2030? In 2050? How will population growth affect the island's resources, such as water $?^{81}$ How can the Dominican Republic, which shares the same ecosystem with Haiti, contribute to the reversal of the latter's man-made catastrophe of deforestation? How can both nations jointly address the staggering, and still growing, HIV epidemic, particularly when the World Bank states that the "Dominican Republic and Haiti together account for 85 percent of the total number of HIV/AIDS cases in the Caribbean"? ${ }^{82}$

Former Haitian president Jean-Bertrand Aristide was fond of saying that Haiti and the Dominican Republic are wings of the same bird; if one wing is broken, the bird cannot fly. He was referring to the more than 200 years of shared collaborative and local economic and social history between Dominicans and Haitians. But the elites of both countries have portrayed each other as geographically and racially distinctive people. I contend that Aristide was right: the metaphorical bird of Hispaniola cannot fly with broken wings. No matter how many more paved roads, modern tourist resorts, and quasi-white Miss Universe contestants the Dominican Republic proclaims to demonstrate its eternal superiority over Haiti, it too is a broken wing. An inclusive and generous vision may, by contrast, finally allow both halves of Hispaniola to take ethereal and triumphant flight. Let us hope.

\section{Acknowledgments}

I was able to undertake the research and travel for the completion of this article thanks to several funding sources. A PSC-CUNY award from the CUNY Research Foundation and a National Endowment of the Humanities grant allowed me the wonderful opportunity to present my ideas and receive important feedback at several conferences. I would like to thank John Jay College Sponsored Programs' Jacob Marini and Pauline Haralambopoulos for their tireless support in helping me through the grant-application process. I would also like to thank the three anonymous reviewers at Genocide Studies and Prevention whose concise and instructive comments have only served to strengthen the article. Adam Jones was gracious enough to read several drafts (while on vacation no less!) and offer invaluable structural comments that forced me to rethink my overall thematic framework. Thank you, Adam. Michel Wucker read an earlier draft, and I thank her for her always kind and indefatigable support. Lastly, I would like to thank Zaire Dinzey for her skillful and perspicacious eye and her constant support of and excitement about my desire to see that all Dominicans, regardless of either skin color or national origin, be treated with equality in the Dominican Republic. 


\section{Notes}

1. By mid-May 2005, Dominican newspapers reported more than 2,500 persons deported. See "Denuncia persecución indiscriminada: Obispo Mao pide detener repatriación de haitianos," Hoy.com, 16 May 2005, www.hoy.com.do (accessed 16 May 2005). By mid-June, 600 more Haitians (in only five days) had been deported from the Dominican Republic: "Autoridades dominicanas repatrían 600 haitianos en cinco días," Hoy.com, 15 June 2005, www.hoy.com.do (accessed 15 June 2005). There are some unconfirmed estimates that place the number of Haitians deported by May 2005 at over 10,000.

2. "Colchones, camas, sillas, estufas y otros enseres para el hogar fueron reducidos a cenizas por las acciones de moradores de aquí, quienes decían vengar la muerte de Maritza Núñez y las heridas que recibió su esposo Domingo Antonio Luna, en un asalto en su vivienda y colmado Luna la madraguda del Lunes [Mattresses, beds, chairs, stoves and other household goods were reduced to ashes by the actions of local residents who decided to avenge the death of Maritza Núnez and the injuries received by her husband, Domingo Antonio Luna, in an attack on their home and store Luna early on Monday morning.]. See "Arrasan casuchas haitianas en Hatillo," El Nacional, 11 May 2005, www.elnacio nal.com.do (accessed 11 May 2005). I personally saw and photographed the looted homes. Even three weeks after my arrival, the debris mentioned in this article was visible lying outside the homes where, just a month before, Haitians had been living.

3. Of the 9,183,984 residents of the Dominican Republic (July 2006 estimate), one million are estimated to be Haitians and their descendants. For Dominican population figures, see the CIA World Factbook, https://www.cia.gov/cia/publications/factbook/geos/dr.html (accessed 6 October 2006); for more information on the range of Haitian population figures in the Dominican Republic, see Human Rights Watch, "Background," in "Illegal People": Haitians and Dominico-Haitians in the Dominican Republic (2002), http:// www.hrw.org/reports/2002/domrep/domrep0402-02.htm (accessed 6 October 2006).

4. For the seminal article on the autonomous nature of the pre-1937 border and local Dominican-Haitian collaboration, see Lauren Derby, "Haitians, Magic, and Money: Raza and Society in the Haitian-Dominican Borderlands, 1900 to 1937," Comparative Studies in Society and History 36 (1994): 488-526.

5. By "ethnic cleansing" I mean the "deliberate, systematic, and forced removal of a particular ethnic group from a specified territory." See Israel Charny, ed., Encyclopedia of Genocide, vol. 1 (Santa Barbara, CA: ABC-Clio, 1999), 215.

6. According to one sixty-eight-year old, one of the handful of Haitians remaining in the outlying areas of Hatillo Palma, "They [Dominicans] arrived at night and started shooting in the air, saying they were guards. When people [Haitians] walked outside, the men started swinging their machetes." See Peter Prengaman, "Attacks Strain HaitianDominican Relations," Chicago Sun-Times/Associated Press, 11 June 2005.

7. At the time, the running debate between human-rights and government officials centered on the use of deportations. Human-rights officials denounced the arbitrary deportations of entire communities following the Maritza Núñez murder; conversely, immigration and local-government officials argued that the deportations were necessary to save Haitians from vigilante mobs seeking revenge. The mayor of Hatillo Palma, Joselín Espinal, asserted that she personally authorized the vehicles to transport Haitians from the town to avoid a massacre: "No me arrepiento de haber socorrido a los Haitianos, ya que si no eran auxiliados, los muertos se iban a contar por muchos [I do not regret saving the Haitians because if not, many dead people would be counted]." See "Opina solo el tiempo resolverá problema haitianos en Hatillo," El Nacional, 13 May 2005, www.elnacional.com.do (accessed 13 May 2005).

8. I have changed the names of the Haitians and Dominican-Haitians for their protection. Solidaridad Fronteriza is a community border organization headed by Father Regino Martinez. See Solidaridad Fronteriza, http://solidaridadfronteriza.blogspot.com/(accessed 6 October 2006). 
9. "Pedro," interview with the author, Batey Libertad in Valverde Mao, May 2005.

10. See HRW, Illegal People, para. 5.

11. Father Jesus Alvarez, interview with the author, Enriquillo, Dominican Republic, 1 June 2005.

12. "Inaceptable" (editorial), El Nacional, 13 June 2005, 10 (my translation).

13. For the timeless and classic history of the Haitian Revolution, see C.L.R. James, The Black Jacobins: Toussaint L'Ouverture and the San Domingo Revolution, 2nd ed. (New York: Vintage, 1963).

14. Frank Moya Pons, The Dominican Republic: A National History (New York: Hispaniola Books, 1995), 106.

15. Ibid., 112 .

16. According to Pedro San Miguel's insightful book on Dominican intellectual history, "the separation from Haiti was a reactionary movement in defense of Spanish culture, which had been threatened by the measures imposed by the [Haitian] occupiers... The struggle against Haiti was the crucible in which the Dominican nation was formed." Pedro San Miguel, The Imagined Island: History, Identity, and Utopia in Hispaniola (Chapel Hill: University of North Carolina Press, 2005), 56.

17. Indeed, the first Dominican national anthem of 1844 began with the words "To arms, Spaniards!" and contained no reference to Dominicans. But in this anthem, the seeds of anti-Haitianism are evident: “ ${ }_{\mathrm{i}}$ No hay piedad! El haitiano insolente,/ penetrando hasta nuestros hogares,/ profanó nuestros templos y altares... [There is no mercy! The arrogant Haitian, penetrating even our own homes, disrespecting our temples and altars ...]." See Félix Maria Del Monte, "Canción Dominicana," http://www.jmarcano.com/mipais/ cultura/poesia/himno1.html (accessed 6 October 2006).

18. See Pons, The Dominican Republic, 210-18.

19. The most comprehensive document-based source that examines the question of the massacre and the casualty rate is Bernardo Vega's two-volume Trujillo y Haiti. In Volume 1, Vega concurs with both Haitian diplomat Jean Price-Mars and Haitian President Elie Lescot that 12,136 people were killed and 2,419 injured during the massacre (vol. 1, 386). Interestingly, a few years later, after reviewing vague US diplomatic sources, Vega would revise and subsequently decrease his casualty numbers, stating that only 4,000 to 6,000 people had been killed during the massacre (vol. 2, 347). Bernardo Vega, Trujillo $y$ Haiti, vol. 1: 1930-1937 (Santo Domingo: Fundación Cultural Dominicana, 1988); vol. 2, 1937-1938 (Santo Domingo: Fundación Cultural Dominicana, 1995).

20. PSF Box 70 State: 1937 FDR Library, Hyde Park, NY, 2. Norweb writes that "on three successive nights groups of Haitian men, women and children were herded to the end of the customs wharf at Monte Cristi and there dispatched by the soldiers. They were clubbed over the head and thrown into the sea where the sharks completed the task by destroying the evidence" (3).

21. "Dominican Republic and Haiti, Agreement regarding Frontier Questions and the Settlement of all Disputes resulting from the Events which have occurred during the Last Months of the Year 1937 near the Frontier between the Two Countries," 31 January 1938, League of Nations Treaty Series 187, pts. 4328-49, 176 [Haiti-DR Treaty]. Four years later the Dominican government continued to deny responsibility for the massacre, stating that it was "caused by bands of Haitian marauders that have always roamed around the border regions, raiding Dominican territory and depriving native farmers of the fruits of their toil." See Consulate of the Dominican Republic, "Bulletin of Information on Dominican-Haitian Border Incidents" (New York, 1941), 2.

22. Haiti-DR Treaty, ibid.

23. The lack of sites dedicated not only to the memory of events surrounding the 1937 massacre but to Dominican and Haitian collaboration is tragic. A nation like the Dominican Republic, which embraces globalization and democracy, is still slow to preserve this neglected past. With a little help, however, the Dominican Republic could engage its past more forcefully. For example, the International Coalition of Historic Site Museums 
of Conscience "is a network of historic sites remembering struggles for democracy from centuries ago to the recent past.... Whether it interprets great good or great evil, whether it preserves a cultural or an environmental resource, a historic site has unique power to inspire social consciousness and action. By opening up new conversations about contemporary issues in historical perspective, historic sites can become new town halls, central to civic life and democracy." See the International Coalition of Historic Site Museums of Conscience, "About the Coalition," http://www.sitesofconscience.org/eng/ about.htm (accessed 6 October 2006).

24. Many times, during these deportations, Dominicans I spoke with-from farm workers and maids to taxi drivers, students, and teachers-mentioned the 1937 massacre in arguing how unchecked immigration could lead to a viable repetition of these violent policies.

25. Charny, Encyclopedia of Genocide, vol. 1, 255.

26. “Tropas elite patrullaran la frontera," Hoy.com, 28 November 2002, www.hoy.com.do (accessed 28 November 2002). An interview I conducted in December 2003 with the ultranationalist and influential Dominican congressman Pelegrín Castillo, the border was mentioned as the weakest point of Dominican sovereignty; Castillo even managed to connect anti-Haitianism with Al-Qaeda. According to him, "when Osama Bin-Laden decides to take a vacation in the Caribbean, he is going to come in through the Dominican-Haitian border."

27. Between August and December 2004, 3,264 Haitians were arrested at the border and deported. See "Reclaman drasticidad contra los traficantes de haitiano," Listin Diario, 28 January 2005), www.listindiario.com.do (accessed 28 January 2005); also see "Apresan mas de 400 haitianos mediante 'Operación Vaquero,'” Diario Libre, 14 December 2004, www.diariolibre.com (accessed 14 December 2004).

28. Joaquín Balaguer, La isla al revés (Santo Domingo: Librería Dominicana, 1983).

29. Congressman Pelegrín Castillo, interview with the author, Santo Domingo, Dominican Republic, 8 December 2003.

30. See Jared Diamond, "One Island, Two Peoples, Two Histories: The Dominican Republic and Haiti," in Collapse of Empire: How Societies Choose to Fail or Succeed, by Jared Diamond, 329-57 (New York: Viking, 2005). For a recent, informative, and moving journalistic account of Haiti's environmental situation, see Tim Collie, "All Haiti Is Being Destroyed"; "It's an Unnatural Disaster, a Man-Made Disaster"; "We Know That This Is Destroying the Land, But Charcoal Is What Keeps Us Alive"; and "Haiti: The World Doesn't Have Any Idea How Bad the Situation Is Getting," The South Florida Sun-Sentinel, 7 December 2003.

31. Ervin Staub, "Predicting Collective Violence: The Psychological and Cultural Roots of Turning against Others," in Collective Violence: Harmful Behavior in Groups and Governments, ed. Craig Summers and Eric Markusen, 195-209 (Lanham, MD: Rowman \& Littlefield, 1999), 202.

32. "Hallan cadáveres de dos haitianos en vía," El Nacional, 12 May 2005, www.elnacional. com.do (accessed 12 May 2005).

33. See "Policía investiga muerte haitiano Pedernales," El Nacional, 25 May 2005, www.elnacional.com.do (accessed 25 May 2005).

34. See Minority Rights Group International, "Dominican Republic Warned of Ethnic Cleansing Charge," ReliefWeb, 18 May 2005, http://www.reliefweb.int/rw/RWB.nsf/ db900SID/ACIO-6CHKYP? (accessed 6 October 2006). According to the MAR (Minorities at Risk) Project, which monitors 284 ethnic groups whose population exceeds 500,000, "future abuses and social discrimination against Haitians seems likely. Haitians are likely to be deported and utilized as seasonal laborers." See MAR, "Assessment for Haitian Blacks in the Dominican Republic," 31 December 2004, http://www.cidcm.umd.edu/inscr/mar/ assessment.asp?groupId $=4201$ \#risk (accessed 6 October 2006).

35. Since dark skin is the major criterion for being targeted for deportation, any black person is subject to roundups. During the meeting, therefore, deputy immigration director Juan Isidro Pérez told students, "From today forward you all can walk without fear through our 
streets but we advise you to carry your personal documents and the ID that accredits you as university students" (my translation). See "Haitianos reclaman garantías," Hoy.com, 15 June 2005, www.hoy.com.do (accessed 15 June 2005).

36. The lone survivor, twenty-year-old Bernius Pierre, told authorities that "one of the attackers wore a police uniform and had a shotgun." See "Dominican Republic promises probe of Haitians' deaths," 25 August 2005, http://www.alertnet.org/thenews/newsdesk/ N25571232.htm (accessed 25 August 2005).

37. "Haiti Recalls Envoy over Deaths," BBC News Online, 26 August 2005, http://news. bbc.co.uk/2/hi/americas/4188322.stm (accessed 6 October 2006).

38. Of the nine reported Haitian murders, three are emblematic of these crimes. First are the deaths of two Haitians electrocuted near Santo Domingo after unknown persons booby-trapped their house, as documented in interviews by MUDHA in Santo Domingo. (MUDHA is headquartered at Calle Pedro A. Lluberes No. 1, Gazcue, Santo Domingo, República Dominicana.) Second is the murder, rape, and dismemberment of a seven year-old girl, Siliana Marcolé Pié. She suffered several bodily injuries including a stab wound to her vagina, and, sadistically, her eyes were removed. See "Matan, mutilan niña haitiana," El Nacional, 22 September 2005; MUDHA also has its own investigative field notes. Third, in the same month, are the two Haitians who were shot, and their bodies thrown off a bridge, in the neighboring city of Santiago. One newspaper article states that "this zone has been very sensitive with respect to the topic of Haitians since the murder of the woman in Hatillo Palma, whose death was attributed to Haitians. The situation unleashed a movement of vengeance that had national repercussions." See "Encuentran cadáveres de 2 hombres en Jamao," Diario Libre, 23 September 2005, http:// www.diariolibre.com/app/article.aspx?id=44595(accessed 6 October 2006).

39. "The police and military quickly began detaining dozens of suspected Haitians, ostensibly for their own protection. As many as 250 were arrested in Mao, Jaibón and other towns in Valverde, according to one report, and 200 agricultural and construction workers of Haitian origin were deported from the cities of Moca and Santiago further east." "New Attacks on Haitians," Resource Center of the Americas Update \#810, 7 August 2005, http://www.americas.org/item_21125 (accessed 6 October 2006).

40. I happened to arrive in the town of Villa Trina two weeks after this attack. The scene was surreal; it looked as though a bomb had exploded. Charred debris was everywhere. According to Dominican locals and relatives who accompanied me to the site, the enraged crowd resembled a sea of people descending upon the town, destroying everything in their wake. People who see the photographs I took are shocked at the destruction. See “Ten Haitians Killed?" Resource Center of the Americas Update \#828, 12 December 2005, http://www.americas.org/item_23632 (accessed 6 October 2006).

41. I would like to thank Dr. Ibrahim Sundiata for the perspicacious observation that the 1937 massacre of Haitians represents the largest and most concentrated twentieth-century collective lynching of black people in the Americas.

42. See EQUIPO ONE-RESPE, Informe de Investigación acerca del prejuicio antihaitiano en la ciudad de Santiago, de la Republica Dominicana: un aporte a la comprensión y al acercamiento de dos pueblos (Santo Domingo: Centro de Estudios Sociales Padre Juan Montalvo, S.J., 1994), 18.

43. See Kevin Reilly, Stephen Kaufman, and Angela Bodino, introduction to Part 2, "Toward a Definition of Racism: Some Test Cases," in Racism: A Global Reader, ed. Kevin Reilly, Stephen Kaufman, and Angela Bodino, 15-44 (New York: M.E. Sharpe, 2002), 15.

44. See Howard French, "Santo Domingo Journal, His Two Burdens: Haiti and Balaguer," New York Times, 14 April 1994, A4. Incidentally, the main airport in the Dominican Republic's capital of Santo Domingo was recently renamed Dr. José Francisco Peña Gomez Airport.

45. See "Invisible Dominicans," DR1 Daily News, 28 March 2005, http://dr1.com/news/2005/ jan_mar_05.shtml (paid access). 
46. "Ethnic Haitian children who are born in the Dominican Republic are routinely denied Dominican birth certificates, the principal form of proof of citizenship used for minors. At hospitals, undocumented parents are typically unable to obtain 'maternity papers' (papeles de maternidad) that attest to the date and location of their children's birth. Some hospitals have facilities for registering births and issuing birth certificates, but these services too are frequently denied undocumented Haitians." Human Rights Watch, "Citizenship and Proof of Dominican Identity," in "Illegal People": Haitians and DominicoHaitians in the Dominican Republic (2002), http://www.hrw.org/reports/2002/domrep/ domrep0402-04.htm\#P444_94766.

47. See Silvio Torres-Saillant, "Para legislar la crueldad," Rumbo, 10 July 2000, 56.

48. Ibid.

49. See "Quince haitianas parieron en un día en hospital Santiago," El Nacional, 22 July 2004, www.elnacional.com.do (accessed 22 July 2004).

50. Ibid. One anti-Haitian reader wrote to the newspaper as follows: "Be careful if you give Dominican citizenship to those people; you have to put them in a truck and send them to the other side now that it is easy to catch them so that they won't do harm afterwards. Long live Duarte and the Dominican Republic." (Juan Pablo Duarte was the founding father who helped usher in Dominican independence in 1844.)

51. Constitucion Politica de la Republica Dominicana de 2002, title III, s. I, art. 11, http://www.georgetown.edu/pdba/Constitutions/DomRep/domrep02.html (accessed 6 October 2006).

52. HRW, "Citizenship and Proof of Dominican Identity."

53. See Las Niñas Yean y Bosico v. República Dominicana, Sentence, Corte Interamericano de Derechos Humanos (8 September 2005), http://www.corteidh.or.cr/docs/casos/articulos/ seriec_130_esp.pdf (accessed 18 October 2006).

54. "Dominican Republic Told to Give Haitians Documents," Miami Herald, 14 October 2005, $12 \mathrm{~A}$.

55. See "Estiman radical fallo Suprema," El Nacional, 18 December 2005, www.elnacional. com.do (accessed 18 December 2005). For the complete Dominican Supreme Court ruling in Spanish, see http://www.suprema.gov.do/novedades/sentencias/inconstitucionalleydemi gracioncertificada.htm (accessed 6 October 2006). For a brief but excellent legal synopsis of the development and impact of the 2005 Inter-American Court ruling in the Dominican Republic, see David C. Baluarte, "Inter-American Justice Comes to the Dominican Republic: An Island Shakes as Human Rights and Sovereignty Clash," Human Rights Brief 13, no. 2 (2006): 25-38, https://www.wcl.american.edu/hrbrief/13/2baluarte.pdf?rd=1 (accessed 6 October 2006).

56. See Roger Plant, Sugar and Modern Slavery: A Tale of Two Countries (London: Zed Books, 1987). "The Haitian workers, then as now, typically live in bateyes-company towns located within the sugar plantations. Some have electricity. Most lack running water. There are no phones, no playgrounds, and no mattresses on many of the rickety beds. The workers earn, typically, the equivalent of $\$ 2.50$ a day, out of which they often must pay a percentage for company social security and pension funds-money, they say, they never see again." Danna Harman, "Haitian Cane-Cutters Struggle," Christian Science Monitor, 1 February 2006, http://www.csmonitor.com/2006/0201/p13s02-woam.html (accessed 6 October 2006).

57. See Gary Younge, "Haitian Children Sold as Cheap Labourers and Prostitutes for Little More Than £50," The Guardian, 22 September 2005, http://www.guardian.co.uk/ international/story/0,1575268,00.html. In Haiti, those children who work as domestics are called restaveks. "This centuries-old practice places children, called 'restaveks' (derived from the French words 'rester avec' meaning 'to stay with'), in situations that sometimes lead to exploitation. Although many restaveks receive adequate care, some are placed in slave-like conditions and are subject to violence, threats and other forms of physical and mental abuse. To a lesser extent, restaveks are sent to the United States, France, Canada and the Dominican Republic." US State Department, "Country Narratives: Countries H 
through P," in Trafficking in Persons Report (2002), http://www.state.gov/g/tip/rls/tiprpt/ 2002/10680.htm (accessed 6 October 2006).

58. For background on the Dominican smuggling tragedy, see "Confusion, Panic in the Deaths of 24 Haitians," Dominican Today, 12 January 2006, http://www.dominicantoday.com/app/ article.aspx?id=9198 (accessed 6 October 2006). For the Mexican crossing see Jorge Ramos, Dying to Cross: The Worst Immigrant Tragedy in American History (New York: HarperCollins, 2005).

59. Council on Foreign Relations, "CPA Action Plan for Preventing Ethnic Violence in Indonesia" (transcript), 3 March 1998, http://www.cfr.org/publication/3217/cpa_action_ plan_for_preventing_ethnic_violence_in_indonesia.html (accessed 6 October 2006).

60. Luis Dalmau, "Leonel ve RD al borde colapso económico," El Nacional, 8 November 2003. In the same interview, President Fernandez went on to say that Haitians "constitute a threat to Dominican national security."

61. Interestingly, there are many non-Haitians, such as Germans, who are a threat to the nation but who, because they are white and viewed as tourists, are not stigmatized as criminals. According to one article citing a German Federal Criminal Police Office (BKA) official, the Dominican Republic "has become a 'retirement zone for criminals' sought by authorities for drug trafficking, pedophilia, fraud or tax evasion, among others. According to the sources, the lax entry conditions applied in the Dominican Republic makes it easy for criminals to mingle with more than 30,000 German residents in the country." See "D.R. is Haven for German Criminals," DR1 Daily News, 30 September 2005, www.dr1.com (paid access).

62. Frank Viñals, "Kosovo y Haiti," Listin Diario, 3 March 1999, 6A.

63. See R.A. Font Bernard, "Ellos' y 'nosotros," El Hoy, 13 August 2004), 17.

64. Adriano Miguel Tejada, “Albano-Kosovares = haitianos = barahoneros?” Rumbo, 12 April 1999, 45. In a letter to the head of the Dominican Armed Forces, the economist Pedro Manuel Casals Victoria wrote that "if we do not act in a quick and convincing manner, a bloody conflict will be provoked between Haitians and Dominicans to justify a collective UN intervention and create a Kosovian solution ... as a citizen of the Republic, I exhort you to act with efficiency without delay, and if necessary, to expel all the Haitian invaders and return them to their territory." "Aboga repatriación masiva de haitianos," El Nacional, 3 February 2005, www.elnacional.com.do (accessed 3 February 2005).

65. Joaquín Ricardo, "Un documento para la comprensión de la problemática domínicohaitiana," Listín Diario, 16 March 1997, 9A. The president of one of the most important and conservative political parties was quoted in a newspaper as saying that because of a failed immigration policy, the nation has become "a storehouse of undocumented Haitians... Understand that between us, the government, businesspeople, politicians and civil society, we have to coordinate a migratory policy that defends the interests and sovereignty of Dominicans." "Quique dice RD es un depósito de haitianos," El Nacional, 11 October 2005, www.elnacional.com.do (accessed 11 October 2005).

66. José Miguel Soto Jimenez, "Grave amenaza," El Hoy, 23 April 1999, 17. The rhetoric of a "Haitian threat" is also seen in the tourist industry, where the "president of the National Council of Borders, Radhamés Batista, said he is alarmed at the Haitian penetration and its presence in the tourist centers of Bávaro and Puerto Plata, which comprise $80 \%$ of the labor and are in violation of the Work Code" (my translation). "Haitianos se adueñan trabajo en el turismo," Hoy.com, 5 July 2006, www.hoy.com.do (accessed 5 July 2006).

67. For Santana and others, if Haitians are not deported, their increasing numbers will destroy the Dominican environment until it is much like Haiti's. See "Santana apoya repatriación haitianos," El Siglo, 3 February 1997, 5.

68. "Oberti estima que las repatriaciones deben ser tratadas con sensibilidad," Listin Diario, 5 February 1997, 14A. Even diplomats, including the former French ambassador to Santo Domingo, Jean Claude Moyret, whose own nation is partly responsible for Haiti's current economic and political malaise, stepped into the national immigration debate, saying Dominican Republic could not support more Haitian refugees due to the political 
collapse in post-Aristide Haiti. See "Enviado France dice RD no puede recibir refugiados," El Nacional, 24 February 2004, www.elnacional.com.do (accessed 24 February 2004).

69. Bernardo Vega, "Las deportaciones civilizadas de haitianos," Listin Diario, 8 August 1995, 6. Among government officials there is a general pro-deportation sentiment, and an alarmist knee-jerk reaction against the rise in the Haitian population. For example, Dominican Secretary of Labor José Ramón Fadul was quoted as saying that his government is trying to "de-Haitianize" the country, as a way to reduce Haitian manual labor. See "Fadul: Gobierno trata de 'deshaitianizar' el país," Listin Diario, 4 April 2005. For alarmist reaction among Dominican elected officials fearing that "in a few years, we will all be Haitians" as a result of unchecked immigration along the border, see "Autoridades estiman alarmante la entrada de ilegales haitianos," Listin Diario, 27 January 2005.

70. Vega, "Las deportaciones civilizadas," 6.

71. Miguel Martínez, "Councilmember Martínez and advocates call for protection of the human rights of Haitians in the Dominican Republic," news release, 25 July 2005, www.council membermartinez.org/forms/Release_HaitianHumanRights7_2005.doc. Also see Edwidge Danticat and Junot Diaz, "The Dominican Republic's War on Haitian Workers," New York Times, 20 November 1999.

72. "In 2004, PADF began an important new initiative along the Haiti-Dominican Republic border designed to bolster ties between the two countries and improve living conditions on both sides of this traditionally conflictive zone. Through a five-year USAID grant, the Frontyè Nou - Nuestra Frontera (Our Border) program is building institutional capacities of 110 Haitian and Dominican non-governmental organizations to deliver vital community services in health, education, human rights, agriculture, natural resource management, women's development, and disaster assistance." Pan-American Development Foundation, "NGO Capacity Building," http://www.padf.org/portal/alias_Rainbow/lang_en/ tabID_3502/DesktopDefault.aspx (accessed 18 October 2006).

73. On my trip to Berlin in December 2004, I could see how post-1945 Germans used architecture to remember their past. I wondered why there were no Dominican symbols or monuments commemorating the 1937 Haitian Massacre. What was more startling was how Germans my own age understood that, although they were not alive during the Holocaust, it was nevertheless their legacy. In the Dominican Republic, there is no collective feeling of accountability for the massacre of 1937 . Neither have Dominicans been taught that they bear responsibility for this crime, or that there is no moral statute of limitation on their reprehensible past.

74. For the sake of preserving Latin-American solidarity and the Good Neighbor Policy, President Roosevelt failed to scorn Trujillo, either publicly or privately. All was forgotten when the United States entered World War II against Germany and Japan, allowing Trujillo to conveniently declare war against the Axis Powers. For Roosevelt's Good Neighbor Policy in the Dominican Republic, see Eric Roorda, The Dictator Next Door: The Good Neighbor Policy and the Trujillo Regime in the Dominican Republic, 1930-1945 (Durham, NC: Duke University Press, 1998), 127-48. Sadly, President Roosevelt's failure to intervene in the massacre, let alone punish Trujillo and his government, is consistent with the way in which various US governments in the twentieth century were consistently slow and silent in reacting to genocides. See Samantha Power, "A Problem from Hell": America and the Age of Genocide (New York: Perennial, 2002), xvii.

75. In El Mozote in 1981, Salvadorean soldiers of the Armed Forces massacred nearly 800 people in their war to eradicate the country's Communist insurgency. See Ian Urbina, "OAS to Reopen Inquiry into Massacre in El Salvador in 1981," New York Times, 8 March 2005, A7. Near the end of World War II in Trieste, Italy, "Communist partisans from neighboring Yugoslavia rounded up Italians in anti-Fascist raids and condemned them to execution by firing squads. Between 5,000 and 15,000 people were shot and dropped into the pits of the Carso mountain range. Some were alive when they were forced into the 
ditches." Jason Horowitz, "Italy Belatedly Recalls Thousands Killed in World War II Massacre," New York Times, 13 February 2005, N7.

76. Benedict Anderson, "Indonesian nationalism today and in the future," New Left Review, May/June 1999, 18.

77. Frank Bruni, "In Benetton's hometown, colors are not united," New York Times, 27 September 2002, A4.

78. In early December 2003, I conducted twenty-five video interviews for a larger project with Dominicans of Haitian descent in Santo Domingo. I would like to thank Sonia Pierre, executive director of MUDHA, who was gracious enough to introduce me to the Dominican-Haitian community.

79. Sonia Pierre, video interview with the author, Santo Domingo, Dominican Republic, December 2003.

80. See Soto Jimenez, "Grave amenaza."

81. The question of access to and jurisdiction over water supplies is not limited to the Dominican Republic but will be a major global issue in the next fifty years. At an August 2004 World Water Week Conference in Stockholm, Sweden, Professor William Mitsch of the Department of Natural Resources at Ohio State University stated, “I don't know what will shake these regions out of complacency other than the fact there will be droughts, pestilence and wars that break out over water rights." "Scientists Say Risk of Water Wars Rising," Science Reuters, 23 August 2004, www.news.yahoo.com/news (accessed 18 October 2006).

82. World Bank, "Caribbean: World Bank Approves $\$ 155$ Million to Support Programs to Fight HIV/AIDS,” news release no. 2001/412/LAC, 28 June 2001, http://web.worldbank.org/ WBSITE/EXTERNAL/COUNTRIES/LACEXT/DOMINICANEXTN/0,,contentMDK: 20014469 menuPK:337789 pagePK:2865066 piPK:2865079 theSitePK:337769,00.html (accessed 18 October 2006). In Haiti, HIV/AIDS affects 5\% of the population. As of 2001, 200,000 Haitian children have been orphaned by AIDS. "The Dominican Republic has 120,000 people living with AIDS (PLWAs), nine times the total number of reported cases. About 20,000 people have died from AIDS in the past decade. HIV/AIDS is the leading cause of death among women of reproductive age. Prevalence is highest (5\% of adults) among low-income groups that include many Haitian immigrants living in rural communities and working on sugar-cane plantations." Patricio V. Marquez, "Dominican Republic HIV/AIDS Prevention and Control Project," World Bank, http://web.world bank.org/WBSITE/EXTERNAL/NEWS/0, contentMDK:20221525 pagePK:116743 piPK: 36693 theSitePK:4607,00.html (accessed 20 October 2006). 